DOI 10.4467/12332135KRA.21.013.14692

\title{
Wystawa „Za obiektywem. Krakowskie zakłady fotograficzne pierwszej połowy XX wieku", 30 września - 6 listopada 2021 r.
}

7 października 2021 r., o godzinie 12, na placu przed Archiwum Narodowym w Krakowie przy ul. Rakowickiej 22E odbył się uroczysty wernisaż wystawy plenerowej „Za obiektywem. Krakowskie zakłady fotograficzne pierwszej połowy XX wieku”, przygotowanej na Dzień Archiwisty obchodzony 30 września. Wystawę otworzył prof. dr hab. Wojciech Krawczuk, dyrektor Archiwum, Marek Świca, dyrektor Muzeum Fotografii w Krakowie oraz dr Barbara Zbroja, kurator wystawy. Na wernisaż przybyli m.in. potomkowie bohaterów wystawy: Gabriela Buzek-Garzyńska, prawnuczka Zygmunta Garzyńskiego, Barbara Kańska-Bielak, wnuczka Zygmunta Garzyńskiego, Anna Piekarczyk, wnuczka Adama Karasia, Ewa Tarnawska-Makara, wnuczka Józefa Kuczyńskiego, Grażyna Tabanja, wnuczka Adama Borowca, Jerzy Buzek-Garzyński, wnuk Zygmunta Garzyńskiego i Maciej Moszew, wnuk Tadeusza Jabłońskiego. Po otwarciu, kurator oprowadziła po ekspozycji, przybliżając sylwetki poszczególnych fotografów, następnie gości zaproszono na poczęstunek.

Bohaterami wystawy są: Adam Borowiec, Zygmunt Garzyński, Jakub Gols, Tadeusz Jabłoński, Adam i Wiktor Karasiowie, Franciszek Kryjak, Wilhelm Kleinberg, Józef Kuczyński, Ignacy (Izaak) Pretzel, Leo (Leon, Leizer) Sprung. Część fotografów była pochodzenia żydowskiego, m.in. Kleinberg, Pretzel, czy Sprung. Ich aktywność zawodowa została brutalnie przerwana wraz z wybuchem II wojny światowej, a później zapomniana. Część ekspozycji poświęcono kobietom - tym samym przypomniano także fotografki całkowicie wyparte z kart historii - przywracając należną im pamięć. Na wystawie przywołano postaci: Pelagii Bednarskiej, Ernestyny Ameisen, Ernestyny Ettinger, Anny Gols, Emilii Guschinow, Klementyny Mien i Anieli Pawlikowskiej.

Na wystawie po raz pierwszy zaprezentowano różnorodne materiały z zasobu Archiwum Narodowego w Krakowie dotyczące wymienionych osób, m.in. dokumenty cechu fotografów, projekty architektoniczne zakładów fotograficznych, wnioski o dowody i paszporty ze zdjęciami bohaterów wystawy, podania o kenkarty fotografów żydowskiego pochodzenia oraz portrety mieszkańców Krakowa. Ekspozycję uzupełniają zdjęcia ze zbiorów Muzeum Fotografii w Krakowie oraz osób prywatnych, w tym spadkobierców fotografów.

Projekt graficzny ekspozycji przygotowała Agnieszka Supernak. Wystawa potrwa do 6 listopada $2021 \mathrm{r}$.

dr Barbara Zbroja Archiwum Narodowe w Krakowie 